\title{
Bissu and Toboto Domain; Lanskap, Islam, dan Negosiasi
}

\section{Febi Triadi}

Department Antropologi, Fakultas Ilmu Budaya, Universitas Gadjah Mada.

Email Coresponden: triadifebi@gmail.com

\begin{tabular}{l}
\hline ARTICLE INFO \\
\hline Keywords: \\
Bissu; Toboto; landscape; \\
Islam; Negotiations. \\
How to cite: \\
Triadi, F. (2019). Bissu \\
and Toboto Domain; \\
Lanskap, Islam, dan \\
Negosiasi. ETNOSIA: \\
Jurnal Etnografi \\
Indonesia. 4(1): $73-90$. \\
DOI: \\
10.31947/etnosia.v4i1.6163
\end{tabular}

\begin{abstract}
This research found a dividing line between the narrative of Bissu and Toboto, in some previous research, they were always singularly narrated. But this Research looks at other phenomena of Bissu, namely Toboto, present and playing a role in their daily lives. That way, this article wants to reveal another narrative that has been supporting the Bissu as a single narrative. It also focused on landscapes, Islam and negotiations, using ethnographic methods, taking the context of research in Pangkep Regency and confirming the data, with Bissu and adat councils in Bone District, making this research conducted from November to December. The analytical technique used is structural-functional, which sees exchange relations between people who have their respective structures and functions. This research found several updates. First, the context in seeing Bissu daily life is always centered on Segeri Subdistrict, but what is in the field, it turns out Bissu residence is not only in Segeri District. Secondly, as far as any behavior deviates from the behavior of Bissu and Toboto, Islam as a religion teaching always returns them to their nature. And thirdly, negotiations between the two camps (adat council and religious leaders) are like a time bomb that is ready to explode at any time.
\end{abstract}

Copyright () 2019 ETNOSIA. All rights reserved.

\section{Pendahuluan}

"Dalam latar kebudayaan Pangkep, bahwa masyarakat kabupaten itu kurang peka dalam merawat benda-benda sejarahnya" (Magassing, 2008).

Terik tanpa permisi memasuki ruangan perpustakaan, kala membaca kumpulan tulisan yang bertajuk Sejarah Kelahiran Pangkep terbitan tahun 2008, ada konteks berbeda dengan apa yang terjadi, memiliki jarak waktu selama sebelas tahun. Apa yang ditemukan dalam perjalanan meneliti bissu dan kekasihnya (toboto), saya berkenalan dengan beberapa orang yang tergabung 
dalam Lembaga Badik Celebes. Mereka sangat konsen dengan isu-isu kebudayaan, apalagi isu mengenai benda pusaka, tiap anggota maupun pengurusnya memiliki benda pusaka, dalam bahasa lokal disebut badik.

Bahwa benar, jika mendengar jargon selalu ada orang baik saat kita bepergian/turun lapangan. Perjumpaan yang tidak disangka ketika menemukan komunitas ini saat sedang melakukan penelitian, karena dengan begitu saya tidak perlu bersusah-paya untuk mencari orang-orang yang mampu menunjukkan tempat dan gambaran umum para bissu. Ketika saya menanyakan kepada mereka tentang konsep toboto, banyak dari mereka yang langsung tertawa kecut merespon pertanyaan ini.

Sebelumnya, toboto adalah seorang lelaki tulen yang menjadi idaman hati bissu. Biasanya ia dipelihara bissu sejak kecil, baik yang memiliki ikatan keluarga dengan bissu, maupun tidak sama sekali. Ditahun 2015 Umar Thamrin, mengemukakan bahwa toboto merupakan anak dari sanak saudara yang diadopsi untuk membantunya dalam kehidupan sehari-hari, jebolan University of California ini menuliskan bahwa selain sebagai asisten pribadi, toboto juga merangkap sebagai belahan jiwa "toboto is professional halper or assistant. But, in the lontara' it mean is soul mate" (Thamrin, 2015).

Sebelum masuk ke ranah toboto, terlebih dahulu saya menjelaskan lanskap tempat mereka. Ketika Sulawesi Selatan berstatus Daerah Tingkat II setingkat kabupaten, lahir dan bermula pada masa kemerdekaan dengan Keputusan Presiden No. 5 Tahun 1960 atas dasar UU No. 29 Tahun 1959 tentang pembentukan Daerah Tingkat (DATI) II di Sulawesi, saat itu Pangkep merupakan salah satu dari 27 kabupaten yang dibawahi Provinsi Sulawesi Selatan-Tenggara (Kaseng, 2008). Itulah mengapa, tepat tanggal 8 Februari 2019 lalu, Pangkep merayakan hari ulang tahunnya yang ke 59 tahun. Di hari ulang tahunnya ini, Pemerintah Provinsi Sulawesi-Selatan memberikan hadia berupa Ambulance Laut. ${ }^{1}$ Ambulans dipilih karena pertimbangan warga yang berada di daerah kepulauan.

Sementara itu, bahasa yang digunakan di juga tergolong unik, karena tempat itu adalah daerah pertemuan, maka beberapa warganya fasih untuk melafalkan bahasa dengan cengkok Makassar sekaligus lihai menutur bahasa Bugis. Selain itu, salah satu informan dalam penelitian ini bahkan menguasai tiga jenis bahasa lokal sekaligus (Bahasa Makassar, Bugis dan juga Dewata²). Namun, dalam menerima orang baru seperti saya, mereka senantiasa menggunakan bahasa pemersatu, yakni bahasa Indonesia.

1 Pemrov Sediakan Kodo Ambulans untuk HUT Pangkep ke 59 dari laman: http:// makassar.tribunnews.com / /2019/01/20/pemprov-siapkan-kado-ambulans-laut-untuk-hutpangkep-ke-59. Diakses 17 Februari 2019, 17.43 WIB

2 Bahasa yang cuma dimengerti oleh komunitas Bissu dan segelintir orang saja, beberapa literatur menyebutkan, jika bahasa ini adalah bahasa Bugis paling halus dan sudah tergolong kuno. 
Penuturan bahasa Indonesia juga dilakukan antara mereka yang berbeda suku, tentu hal ini untuk menghargai dalam menjalin sikap menghormati antara mereka. Sebab, sikap hormat antara orang satu dengan orang lain dapat dilihat dari jenis bahasa yang digunakan (Sumyati, 2006). Bentuk harmonisasi yang dijalin antar dua suku di daerah pertemuan ini, didukung dengan fakta konflik antar suku di Kabupaten Pangkep belum tercatat atau bahkan tidak dapat ditemukan. Selain itu, dari letak batas wilayah yang berdasarkan suku, maka penutur Bahasa Bugis lebih banyak ditemukan ketimbang penutur Bahasa Makassar.

Wilayah administratif Kabupaten Pangkep mencakup tiga belas Kecamatan, empat Kecamatan Kepulauan (lihat Gambar 2), yakni Kecamatan Liukang Tangaya, Liukang Kalmas, Liukang Tupabbiring, Liukang Tupabbiring Utara, sembilan Kecamatan Daratan yakni; Pangkajene, Minasatene, Balocci, Tondong Tallasa, Bongoro, Labakkang, Ma'rang, Segeri, dan Mandalle (lihat Gambar 1) dengan jumlah desa/kelurahan sebanyak 103, dengan jumlah penduduk keseluruhan sebanyak 323.597 jiwa (BPS Pangkep, 2015), berikut letak dalam peta Kabupaten Pangkep.
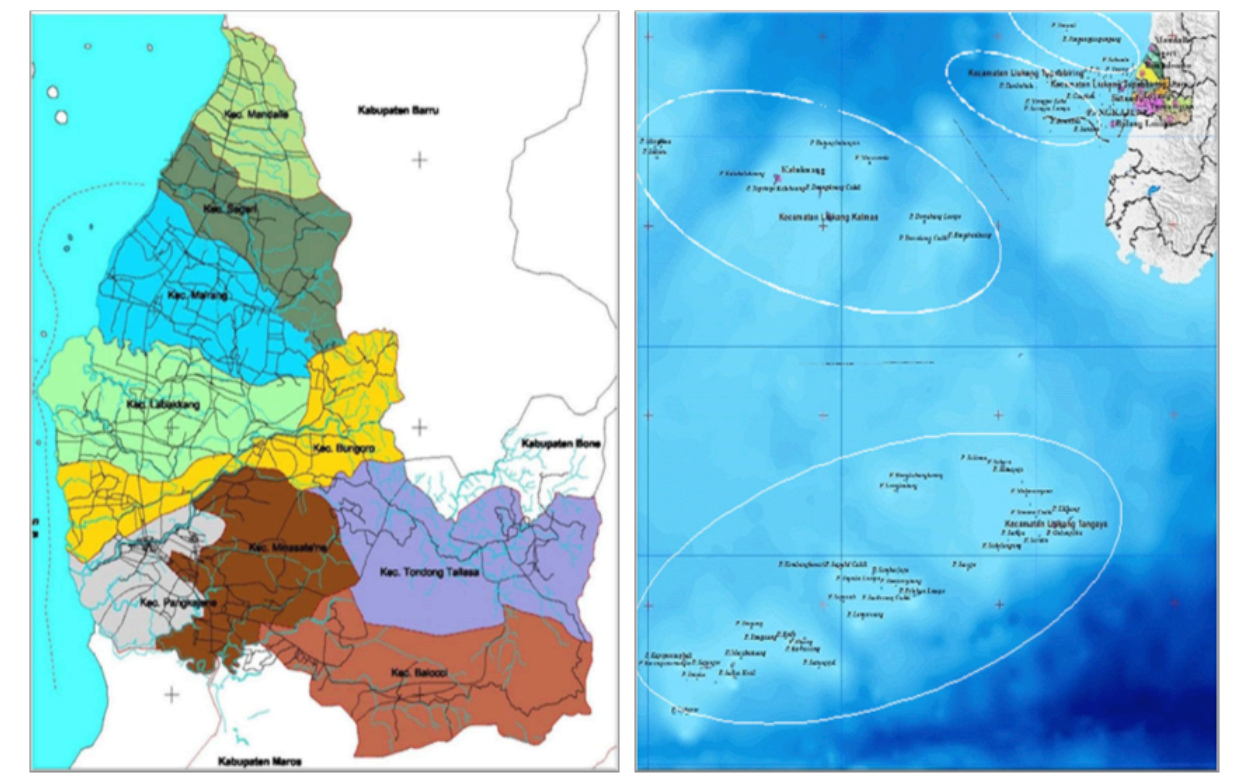

Gambar 1. (kiri tampak dari pembaca) Wilayah daratan. Gambar 2. (kanan tampak dari pembaca) Wilayah kepulauan, Kabupaten Pangkajenne dan Kepulauan Sumber: pangkepkab.go.id

Jika menempuh perjalanan darat dari Ibu Kota Sulawesi Selatan (Makassar), terlebih dahulu harus melewati Kabupaten Maros untuk sampai di lokasi penelitian. Dalam perjalanan menuju arah utara, sepanjang jalan di bagian barat akan banyak menemui tambak milik warga lokal, tambak ini bercampur dengan daerah persawahan sehingga terlihat beberapa selingan sawah dalam hamparan tambak yang mendominasi. 
Pada bagian timur, akan terlihat hamparan sawah yang terhenti karena deretan pegunungan karts, juga menjadi salah satu objek wisata Kabupaten Pangkep, dan jika jeli, maka akan terlihat PT. Semen Tonasa beroprasi. Pada sisi yang lain di bagian utara akan berbatasan langsung dengan Kabupaten Barru, sebelah selatan berbatasan dengan Kabupaten Maros. Tulisan ini menarasikan Kabupaten Pangkep secara keseluruhan, karena dengan pertimbangan data yang didapatkan di lapangan, berbeda dengan narasi peneliti sebelumnya. Dari kajian pustaka yang ada, Bissu yang dinarasikan selalu mengambil konteks di Kecamatan Segeri. Walaupun tidak semua membahas Segeri lewat teritori geografis, namun skop dan bahasannya tetap berkonteks di Segeri, seperti Nurlina \& Soedarsono (1997) mengatakan mesyarakat penganut kepercayaan lokal tolotang yang ada di Segeri. Hakim (2014) mengatakan Saidi, diangkat menjadi puag matoa bissu di Segeri dan menjalani beberapa rangkaian upacara bissu. Selanjutnya Thamrin (2015) menemukan jika bissu, according to the Segeri people, have a significant role in determining the cycle of rice plantation and harvest, trough mappalili. Fajriani (2015) dengan upacara mappalili, warga Segeri menciptakan rasa solidaritasnya sendiri, dalam persiapan dan pelaksanaan upacara tersebut. Terakhir dari Said (2016) menemukan pada masa lampau, pelaksanaan upacara ritual palili yang dipelopori oleh kaum bangsawan dan hartawan Bugis di Segeri.

Dari paparan mengenai bissu dan Kecamatan Segeri di atas, mengindikasikan jika bissu selama ini didekati lewat narasi kegiatan upacara yang dilaksanakan di Segeri, tepanya di rumah arajang. Dalam penelitian ini, justru ingin melihat keseharian bissu diluar dari prosesi upacaranya, sehingga Segeri menjadi konteks yang sekunder. Di lapangan, Bissu tidak tinggal pada satu kecamatan saja, melainkan juga di kecamatan lain, seperti Puang Matoa Nani mengaku sering kembali ke rumah asalnya di Kecamatan Ma'rang, Desa Bonto-bonto, jika di rumah arajang sepi dan perbekalan untuk hidup sudah menipis. Begitu juga Bissu Juleha menetap di Desa Padang Lampe dengan kecamatan yang masih sama, serta Bissu Usman, Baha, Nisa dan Matang juga tinggal dan berasal dari Kecamatan Labakkang namun dengan desa yang berbeda.

Selain itu, dalam tulisan kali ini, saya membawa pewacanaan dari Thomas Gibson untuk melihat negosiasi adat dan Islam bekerja. Baginya, walaupun Islam telah berkembang dan menggeser pemikiran mengenai animisme, namun raja-raja yang berkuasa tidak pernah benar-benar meninggalkan mitos, ritual, dan benda-benda kramat setempat yang melegitimasi kekuasaan mereka (Gibson, 2009). Artinya, kekuasaan yang ada pada penguasa diberkati oleh benda-benda yang dianggap sakral. Itulah kenapa, beberapa kerajaan di Sulawesi Selatan masih memerlukan komunitas Bissu untuk melegitimasi kekuasaan raja atau pemerintahnya. 


\section{Metode Penelitian}

Penelitian ini dilakukan di Kabupaten Pangkep, menggunakan metode etnografi yang bertugas untuk menarasikan suku bangsa lewat sudut pandang native poin of view, dengan menampilkan, merepresentasikan kebudayaankebudayaan masyarakat yang diteliti (Ahimsa-Putra, 1987). Penelitian etnografi sifat datanya cenderung kualitatif, walaupun juga memiliki data kuantitatif, namun perbandingannya masih didominasi oleh data kualitatif. Metode pengumpulannya mencakup pengamatan prilaku, interview (mendalam) dan kondisi material, mementingkan first hand data, yakni data-data yang diperoleh secara langsung (dialami) oleh peneliti (Simatupang, 2017).

Selain itu, penelitian ini berlangsung selama November 2018 hingga Januari 2019. Analisis data yang dilakuakan dengan melihat relasi bissu, toboto dewan adat, dan juga pemuka agama sebagai informan, dengan melihat relasi mereka lewat kajian struktural-fungsional. Artinya, setiap struktur memiliki fungsinya untuk melegalkan pertukaran, pelapisan dan status mereka dalam masyarakat. Struktural-fungsional ini dianggap cocok, karena menampilkan analisis atau deskripsi terhadap struktur masyarakat yang menjadi objek penelitian. Tentu relasi ini akan lebih terlihat saat objek memaknai perannya, dan menelaah relasi pertukaran sosial yang berada dalam kaidah struktur dan fungsinya.

Etika yang berjalan dalam penelitian kali ini menyamarkan beberapa nama informan, karena beberapa data yang didapatkan menyangkut hal yang sangat personal dari informan mengenai hubungan pertukaran yang dilakukan oleh toboto dan bissu. Data yang telah dikumpulkan kemudian klasifikasikan sesuai dengan tema kultural yang muncul dari hasil wawancara, data-data yang muncul kemudian dihubungkan hingga dapat terlihat gambaran secara utuh dan menyeluruh tentang relasi pertukaran dan praktik kekuasaan yang terjadi di antara informan (Spradley, 1980).

\section{Hasil Penelitian dan Pembahasan}

\section{- Bissu, Dulu, dan Sekarang: Sebuah Awal}

Sebagai sebuah awal kemunculan bissu di daerah pangkep, Segeri menjadi tempat arajang yang hilang ditemukan. Berangkat dari situ, hingga saat ini, bissu terus melakukan regenerasi terhadap komunitasnya. Hingga kini, bissu tidak cuma bisa ditemukan di daerah Segeri. Mereka masih bisa menemukan mereka di kecamatan lain, namun masih dalam Kabupaten Pangkep. Meski bissu juga bisa ditemukan di Bone, Soppeng dan Wajo, namun itu perkara lain.

Masa kejayaan bissu dikenal dengan masa sebelum kedatangan Islam, masa ini ditandai dengan masih berjalannya sistem kerajaan, dan segala aturannya yang 
mengikat. Kala itu, kerajaan di tanah Bugis, menggunakan bissu sebagai penanggung jawab spiritualnya. Setelah masuknya Islam di jazirah Sulawesi Selatan, komunitas Bissu memulai pergolakan yang panjang. Namun walaupun kepercayaan terhadap mereka memudar, jasanya tetap digunakan sebagai perias pengantin atau akrab dikenal sebagai indo' botting (perias pengantin), di lain kesempatan jasa mereka juga dipakai sebagai dukun/sandro.

Di masa Islam sudah menyebar dan mejadi agama yang dominan, sekitar tahun 1950-an kehidupan Bissu mulai agak redup, masa suram terjadi ketia munculnya gerakan kelompok DI/TII di Sulawesi, mereka berusaha mengadakan pemurnian terhadap ajaran-ajaran Islam. Kelompok DI/TII menganggap aktivitas bissu sebagai hal yang menyalahi aturan agama Islam dan dikategorikan sebagai hal musyrik (Suliyati, 2018).

Para anggota kelompok DI/TII berusaha melarang aktivitas mereka dan menghancurkan peralatan upacara milik para Bissu. Bahkan banyak dari mereka yang dibunuh, karena dianggap menyalahi kodrat dan tidak mau bertobat. Masa ini merupakan masa yang kelam bagi kehidupan Bissu (Lathief, 2004). Selain itu, mereka juga dianggap membangkitkan feodalisme, karena masih menggunakan sudut pandang kerajaan yang menjunjung tinggi kaum bangsawan. Kala itu juga Sulawesi Selatan mengalami kekacauan, gerakan DI/TII dengan oprasi toba menebar teror bagi beberapa aliran kepercayaan, era transisi ini menjadi saksi perkembangan pengaruh gerakan Islam garis keras Kahar Muzakkar (Harvey, 1974).

Dalam buku yang ditulis Sharyn, di tahun 1957 secara resmi istana Kerajaan Bugis ditutup, namun dilain sisi kegiatannya masih berjalan secara informal. Kaum bangsawan kehilangan kekuasaannya karena posisi mereka digantikan oleh pemerintah nasional terpusat (Davies, 2018). Setelah berakhirnya masa kerajaan dan masuknya ajaran Islam garis keras, penindasan terhadap mereka berlanjut pada tahun 1965. Dari sejarah nasional Indonesia sendiri, tahun 1965 arajang sebagai rumah adat diganyang oleh salah satu ormas pemuda karena dianggap anggota Partai Komunis Indonesia (PKI) (Lathief, 2004).

Dengan selesainya masa orde lama yang ditandai dengan DI/TII dan orde baru yang juga ditandai dengan gerakan PKI, maka datanglah era reformasi. Era ini ditandai dengan revitaslisasi adat, terlibatnya mereka dalam industri pariwisata, menjadikan mereka semakin terpuruk. Pelaksanaan program revitalisasi yang berlangsung, tidak sesuai dengan nilai dan tradisi, akhirnya ritus yang dilakukan hanya sebatas aktivitas seni. Saat Sharyn melakukan penelitian, dirinya menyaksikan beberapa bissu mengikuti pertunjukan adat yang digelar di Bali. bissu bahkan dikirim ke Jepang mengikuti Festival International La Galigo pada tahun 2002. 
Dari hasil pengamatan di lapangan, saat ini komunitas bissu diperhadapkan dengan dua keadaan. Keadaan pertama, bissu sebagai pelaku seni, dan keadaan kedua Bissu sebagai pelaku kebudayaan. Karena semakin massifnya publikasi pariwisata terhadap mereka, maka permintaan untuk tampil dalam beberapa pagelaran seni semakin besar dan tidak dapat tertampung, disitulah ritual mereka dapat dikatakan hanya sebatas pertunjukan seni, ini juga didorong karena sebuah imbalan. Baik berupa mengunjungi suatu tempat yang baru untuk perfom, atau hanya sekedar mendapat imbalan berupa uang.

Bissu sebagai senia, hanya dilihat dari sisi pegelaranannya saja, juga terkait dengan daya pukau yang dimilikinya saat perfom. Setelah terjadi gempa dan tsunami di Palu 28 September lalu, yang juga dikaitkan karena isu ritul. Maka terbitlah juga himbauan pemerintah Provinsi Sulawesi Selatan, yang sangat meyudutkan kegiatan dilakukan bissu. Dari itu, isu bissu sebagai seni untuk sebuah kamuflase. semakin nyata adanya.

Walau himbauan telah diterbitkan, tidak menyurutkan usaha dunia pariwisata masuk dan kembali meraup untung. Ketika ritual mappalili dilaksanakan, mereka didatangi oleh rombongan pariwisata yang entah dari mana asalnya, masuk dan menyaksikan pagelaran bissu. Upaya pemerintah ini ibarat dua sisi mata pisau yang berbeda, satu menhdimbau pelaksanaan mappalili, kedua pelaksanaan tetap berjalan namun praktik koodifikasi terhadap mereka tetap dijalankan.

Sedangkan saat bissu bertindak sebagai pelaku kebudayaan, ada atau tidak adanya pemerintah melalui beberapa instansi terkait, upacara atau ritualnya akan tetap dilakukan. Walaupun juga didatangi dan tidak didatangi wisatawan, ritual sebagai kepercayaan utama mereka akan tetap terlaksana. Seperti membaca doa dan menyalakan lilin tiap malam jum' at di rumah arajang, yang justru tidak tersentu pariwisata. Tentu dengan biaya bissu sendiri, yang juga kadang ditanggung oleh beberapa warga yang masih menggunakan jasa mereka.

Bagi penduduk Pengkep, dengan efek kepercayaan tentang tradisi masih sangat kental, dapat terlihat pada tiap pelaksanaan mappalili (awal turun sawah), kebanyakan dari mereka rela berbondong-bondong untuk membantu jalannya ritual. Selain itu, mereka juga tidak merasa berat untuk saling mengumpulkan uang demi berlangsunya mappalili.

Kala menyaksikan upacara mappalili, saya melihat warga dari berbagai umur berjalan menuju rumah arajang yang menjadi pusat kegiatan. Kebanyakan dari mereka ibu rumah tangga yang juga membawa serta anaknya. Sementara itu, bapak-bapak memilih singgah sepulangnya dari ke Masjid. Namun ada juga beberapa dari warga laki-laki yang enggan untuk menyaksikan upacara itu. Satu yang pasti, bagi mereka untuk melaksanakan upacara yang dilakukan 
bissu, sedikit maupun banyak sumbangan akan terus mengalir baik dalam bentuk apa-pun. Dari praktik itu, mengisyaratkan jika bagaimanapun pandangan mansyarakat tentang mereka, ada saja orang-orang yang terus dan masih menggunakan jasanya.

Berbeda dengan toboto, di beberapa penelitian, memandang toboto sebagai kekasih seorang bissu (Al-Bayqunie, 2016). namun, belum ada yang mampu mengungkap bagaimana relasi mereka bisa terbentuk, tentu relasi itu berbasiskan sebuah pertukaran. Penelitian yang ada hanya menarasikan toboto sebagai sebuah isu kemunduran bagi bissu (Darmapoetra, 2014). Itulah mengapa, saat bertanya konsep toboto, di cerita awal tadi mereka tertawa kecut mengenai itu, ternyata ada hal yang tidak mendapat perhatian lebih dari kisah bissu, yakni toboto.

Warga Pangkep pada umumnya, tidak terlalu mengerti tentang toboto, sebab ini merupakan konsep yang dimiliki dalam komunitas bissu sendiri. Warga lebih memahami mereka (toboto) sebagai seorang ana' piara (anak adopsi), ketimbang mempercayai mereka sebagai idaman hati. Karena itu, tidak mampu dipahami dengan apa yang nampak saja. Motif pertukaran diantara mereka, justru membawa saya lebih memahami relasinya.

Scott dalam penelitiannya di Asia Tenggara menemukan beberapa pertukaran hubungan antara pelindung, selanjnya disebut patron. Dan orang yang dilindungi, disebut klien.

Relationship exchange between roles may be defined as a special case of dyadic (twoperson) ties involving a largely instrumental friendship in which an individual of higher socioeconomic status (patron) uses his own influence and resources to provide protection or benefits, or both, for a person of lower status (client) who, for his part, reciprocates by offering general support and assistance, including personal services, to the patron (Scott, 1972).

Asumsi ini, dapat menjelaskan jika pertukaran juga dapat meliputi personal services atau layanan pribadi, tentu jika ditarik dalam ranah bissu dan toboto.

Konsep toboto, awalnya berasal dari relasi ana' piara dengan seorang bissu. Bukan maksud menjadikan narasi bahwa toboto dibibit sejak kecil, namun lebih pada proses kemanusiaan yang ada di dalamnya. Ana' piara ini diadopsi dari golongan kerabat bissu itu sendiri, seperti yang diungkapkan salah satu bissu yang berhasil saya wawancarai:

"itu dulu, sepuluh $i$ bersaudara, pas meninggal bapaknya, saya ambil mi satu. Karena kasihanka liat kondisi keluarganya, itu mi sekarang yang tinggal sama saya, na bantuka mallaming, sudah mi juga ku belika motor, ku kasi sekolah mi juga" (Bissu Ana, 18 November 2018). 
Apa yang diungkapkan oleh Bissu Ana, menegaskan jika pertukaran yang datang dari bissu berupa pertolongan dari jeratan ekonomi keluarganya, hingga bisa disekolahkan dan dijamin hidupnya. Selain itu, tentu juga ada pertukaran yang didapatkan bissu dari pertolongan itu. Pertama adalah tenaga yang membantnya untuk menjalankan usaha, hasil pengamatan saya dilapangan, jika seorang bissu dikontrak jasanya sebagai perias pengantin, maka toboto yang sibuk mengurusi dekorasi dan segala kebutuhan pesta, setelah itu, barulah bissu berperan merias dan mempersiapkan mempelai pengantin. Kedua, pertukaran ini melingkupi ranah yang sagat pribadi, sebab didalamnya ada mantra dan praktik seksual sejenis. Walaupun saya berhasil mewawancarai Aswan (toboto dari bissu Ana) untuk memperkuat asumsi ini, namun dirinya tentu enggan mengakui itu. Ia hanya mengatakan jika dirinya bekerja tanpa dibayar sedikitpun. Tapi, dari pernyataan itu, sedikit memperkuat asumsi tadi. Walau tidak mendapatkan langsung pernyataan dari toboto, saya justru mendapatkan hasil wawancara itu dari bissu lain memandang bissu Ana.

"kasihan itu Aswan, pernah mi saya suruh tinggalkan itu bissu Ana. Karena na pakai ji tenaganya orang, dikasi sekolah memang dulu. Tapi sekarang tidak mi, mallaming mi saja na kerja itu, apalagi kalau begitu $i$, capek juga orang karena belum pi nanti istirahat laki-laki, minta $i$ lagi. Jadi $k u$ tanya $i$, bilangka pergi mi cari perempuan, supaya bisa ko lepas. (Bissu Virah, 20 November 2019).

Bissu yang satu ini memang tergolong blak-blakan kala diwawancarai, walau begitu, dalam pengamatan saya dirinya juga memiliki toboto yang juga tinggal bersamanya. Apa yang diungkapnya juga mengingatkan saya, jika seorang bissu yang telah tinggal dengan toboto selama tiga tahun, dan ingin melepaskan toboto mereka, harus menikahkanya terlebih dahulu, dan segala tanggungan pesta dibiayai oleh bissu, sebab selama tiga tahun itu, bissu dianggap menghalangi rezkinya (Makkulau, 2008). Walaupun hubungan diantara mereka tergolong menyimang, namun tetap saja dapat diterima dalam masyarakat yang mayoritas Islam. Tentu ini juga mendapat perdebatan yang menarik, nantinya akan banyak saya uraikan dalam pembahasan selanjutnya.

\section{- Lanskap dan Islam: Lapis Struktural}

Secara garis besar kedatangan agama-agama di nusantara dimulai dengan persebaran Hindu-Budha, kemudian Islam dan selanjutnya Kristen. Turunan dari itu, penyebaran Islam dibawah oleh para pedagang muslim, kemudian ulama, lalu disebarkan oleh para raja yeng telah menganutnya (Salihima, 2015). dari situ penyebaran Islam dengan bantuan jalur politik dimulai.

Islam yang ada di kawasan Sulawesi Selatan sebetulnya telah banyak dituliskan oleh beberapa peneliti, mereka sepakat bahwa Islam masuk bagi para pemeluknya di Indonesia tidaklah melalui proses yang dapat dikatakan 
singkat. Namun tahun yang banyak disebutkan dari berkisar antara 1500-an akhir sampai 1600-an. Adapun tokoh yang berperan penting dalam penyebaran Islam di tanah Bugis maupun Makassar adalah Dato' ri Bandang, dengan nama asli Chatib Tunggal. Namanya terkenal seantero negeri lantaran berhasil menjalin hubungan dengan Raja Gowa, saat itu bernama I Mangngurangi Daeng Manrabia, setelah pengislaman dirinya lebih akrab dikenal dengan nama Sultan Alauddin (Gonggong, 1992).

Selain itu, representasi dua suku besar yang ada dalam konteks Sulawesi Selatan, selanjutnya memberikan warna keberislamannya sendiri. Suku Makassar yang direpresentasikan oleh kerajaan Gowa, dan Suku Bugis diwakili oleh kerajaan Bone. Namun konteks Pangkep yang merupakan daerah pertemuan, tidak diketahui persis tepatnya awal masyarakat memeluk agama Islam, tidak seperti kerajaan di tanah Bugis lainnya misal Sidenreng dan Soppeng tahun 1609, ditahun setelahnya 1610 adalah Wajo dan terakhir Kerajaan Bone tahun 1611, dengan raja pertama memeluk Islam adalah La Tenripala Matinroe ri Tallo, Raja Bone ke 11 (Mattulada, 1998).

Suriadi Mappangara dalam tulisannya mengenai sejarah Islam di Sulawesi Selatan, khususnya kerajaan Gowa-Tallo, telah masuk pada masa pemerintahan Raja Gowa X Tunipalangga yang memerintah antara tahun 1546-1565. Fakta ini dapat diketahui dari Gowa ketika itu telah memberikan izin kepada para pedagang Melayu, melalui perantaraan Nahkoda Bonang, mereka kemudian menetap di Mangalekkana, mereka juga mendirikan masjid, dan merupakan yang pertama di Sulawesi Selatan (Mappangara, 2003).

Beberapa ahli sejarah setuju, jika penyebaran Islam yang dimotori oleh kerajaan Gowa tidaklah betul-betul dengan niat yang tulus. Dalam pelaksanaannya, ada hasrat untuk berkuasa. Makanya, kerajaan yang ada ditanah Bugis lebih yakin jika penyerangan yang dilakukan oleh Gowa, bertujuan untuk melebarkan kekuasaan seluas-luasnya. Mattulada menemukan:

Peperangan yang dilancarkan oleh Butta Gowa ke negeri-negeri Bugis dengan dalih penyebaran Islam, ditanggapi oleh keraajaan-kerajaan Bugis sebagai keberlanjutan perang masa lalu, yang sama sekali tidak mempunyai alasan keagamaan, melainkan tujuan-tujuan perebutan kekuasaan tunggal di Sulawesi Selatan (Mattulada, 1998).

Itulah mengapa, dalam beberapa penyebaran Islam yang ada di lanskap Sulawesi Selatan tidak berjalan mulus. Walaupun ada saja jalan penyebaran yang ditemukan melalui jalur pernikahan dengan bangsawan Gowa yang dilakukan oleh raja-raja di tanah Bugis.

Saat menumui salah satu informan yang merupakan ahli sejarah, ia menjelaskan perihal keberislaman yang dianut oleh warga Pangkep. Baginya susah menjelaskan awal Islam di Pangkep, karena selain daerah pertemuan 
Pangkep juga masih berada dalam pengaruh kerajaan Bone, yang saat itu menentang penyebar luasan Islam oleh kerajaan Gowa. Penururan dari salah satu sejarawan Kabupaten Pangkep menjelaskan:

Masuknya Islam di Pangkep susah untuk ditandai itu, banyak sekali versi, kalau versi saya itu, pertama yang memeluk kerajaan Siang, bukan Gowa. Pada tahun 1605, yang dibawah oleh tiga khatib. Muhammad Alwi, Muhammad Sulaiman dengan Abdul Jawwad. Jadi yang pertama di Islamkan itu raja Tallo ke 6, bernama I Mallingkaha Daeng Manyonri, dengan nama Islamnya Sultan Abdullah Awalul Islam. Dan besoknya saat ingin sholat Jum'at di-Islam-kanlah raja Gowa, setelah sholat Jum'at baru di beri nama ke Islam-an Sultan Alauddin, dari situlah Islam berkembang sampai ke sini (Pangkep) (H. Taliu Badau, 11 November 2018).

Pria kelahiran 1946 ini juga menuturkan jika hal yang pasti masuknya Islam di Pangkep pada abad ke XV-XVI. Sejalan dengan itu, pertimbangan juga datang dari literatur dan bukti sejarah yang telah dikumpulkan oleh beberapa peneliti yang konsen dalam ranah itu. Asumsi ini semakin diperkuat dengan temuan Pelras The Bugis, Makassar, and Mandar peoples of South Sulawesi are known as having embraced Islam between 1605 (Pelras, 1993).

Masuknya Islam di Pangkep selalu mengalami kompromi dengan kebudayaan yang ada. Melalui kompromi itu, maka lahir jugalah kata akulturasi. Pencampuran dari keduanya, masih sangat kental bisa di dapati pada warga Pangkep. Ketika awal dilaksanakannya upacara mappalili. Saat itu telah ada rumah baru yang dibangun oleh pemerintah untuk keperluan bissu, di Bugis jika melaksanakan pindah ke rumah baru, biasanya dilakukan prosesi pembacaan kitab barazanji3 ${ }^{3}$, begitu juga dengan rumah baru untuk arajang ini.

Ketika itu rumah arajang di datangi oleh Pak Imam Segeri dan beberapa pengurus masjid untuk melakukan barzanji tidak nampak keraguan dalam raut wajah mereka. Namun mereka lebih dahulu meninggalkan rumah arajang, sebelum ritual mappalili dilakukan. Berselang jedah, Barulah mappano arajang, salah satu rangkaian ritual mappalili dimulai.

Apa yang dilakukan oleh Pak Imam Segeri dan rombongannya ini, tentu menimbulkan pertanyaan. Mengingat, disitu juga ada Pak Camat dan beberapa dewan adat yang ingin mengikuti ritual. Saat saya mewawancarai beliau dilain waktu, dirinya mengungkapkan:

"mereka itu cuma tradisi, sekarang tidak ada mi, orang sini itu, begitu-begitu ji, ada yang percaya, ada tonji yang tidak. Sebagian tonji yang percaya itu, yang lainnya pergi ji menonton" (Pak Imam, 2 Desember 2018).

\footnotetext{
3 Barzanji awalnya adalah sebuah kitab berisi doa-doa, puji-pujian dan penceritaan riwayat Nabi Muhammad SAW yang biasa dilantukan dengan irama atau nada. Isi barzanji bertutur tentang kehidupan Nabi Muhammad SAW, serta silsilah keturunannya, dimulai masa kanak-kanak, remaja, dewasa hingga saat diangkat menjadi rasul. Di dalamnya juga mengisahkan sifat-sifat mulia yang dimiliki, serta berbagai peristiwa unuk dijadikan teladan bagi umat manusia (Kamaruddin, 2017).
} 
Tentu Pak Imam tidak ingin mengambil pusing dengan apa yang mereka percayai, namun hadirnya ia dan melakukan barasanji, menunjukkan sikap yang saling menghargai. Berselang sehari setelah ritual mappalili dilakukan, beberapa warga masih terlihat sibuk untuk mengurusi kegiatan lain, yakni maulid di masjid. Saat maulid dilakukan, umumnya warga membawa male ${ }^{4}$ ke Masjid, untuk turut serta memeriahkan. Walau tak sebanyak warga yang datang saat upacara mappalili, namun saya mendapati bentuk akulturasi paling menarik. Ketika beberapa remaja masjid membawakan male untuk bissu yang ada di rumah arajang. Dengan begitu, walaupun Islam dianggap sebagai ajaran mayoritas, akan tetapi kompromi dengan nilai kebudayaannya masih dapat terlihat dan terasa. Walaupun ada penolakan itu tetap terlihat, bahkan jelas adanya, dalam penelitian Gibson, ia menuliskan:

"Di Sulawesi-Selatan, pergerakan nasionalis berkaitan erat dengan dengan kritik terhadap seluruh ritual yang tidak diperintahkan kitab, berdasarkan doktrin bahwa seharusnya tidak ada jalan baru, bidah dalam praktik-praktik keagamaan. Para pengikut Muhammadiyah tidak menghadiri barasanji, yang menjadikan setiap ritual siklus hidup sebagai arena negosiasi pelik tentang siapa yang boleh dterima di waktu kapan" (Gibson, 2009).

Ini berarti, ada dua pertentangan yang terjadi di dalamnya. pertentangan ini juga menghadirkan dua kubuh yang berbeda, yang akan saya jelaskan dalam poin selanjutnya.

\section{- Pemuka Agama dan Dewan Adat: Jejak Negosiasi Dingin}

Jika mempelajari tipologi masyarakat Kabupaten Pangkep dalam melihat bissu dan toboto, maka akan lahir dua pemikiran yang berbeda. Pertama, kelompok yang pro terhadap mereka, kelompok ini didominasi oleh raja-raja, atau para pemuka adat (arung), mereka serasa ingin mengembalikan masa kejayaan kerajaan, dan melegalkan kebangsawanan, meskipun saat ini status itu masih berjalan, karena dengan begitu mereka bisa kembali berkuasa secara utuh. Kedua, kelompok kontra diwakili oleh warga yang sudah berpikir untuk meninggalkan praktik ritual, mereka didominasi dari warga biasa, namun telah mengenyam pendidikan tinggi, dalam penelitian ini dinamakan Islam fanatik. termasuk dengan tokoh pemuka agama. Walaupun mereka tidak menolak secara penuh, namun penolakan datang dan diperparah justru dari kelakuan

\footnotetext{
${ }^{4}$ Male adalah makanan hiasan yang dibawa pada serangkaian upacara keagamaan masyarakat muslim yang dilaksanakan setiap maulid Nabi Muhammad SAW. Sedangkan Male sendiri terdiri dari kumpulan telur hias berwarna-warni yang disusun berbagai bentuk, seperti masjid, rumah, dan lain sebagainya. Tradisi ini menggunakan telur sebagai ciri khas dari perayaan maulid nabi karena telur terdiri atas tiga bagian, yaitu kulit, putih telur dan kuning telur yang melambangkan fase kehidupan manusia. Kulit dimaknai sebagai kelahiran, putih telur sebagai kehidupan, dan kuning telur sebagai akhir dari kehidupan (Sumber: https:/ /id.wikipedia.org/wiki/Tradisi_Male).
} 
bissu dan toboto sendiri, meskipun tulisan ini, saya berusaha untuk tidak menyudutkan salah satu dari mereka.

Sebelum masuk dalam ranah perdebatan antara dewan adat dan pemuka agama, baiknya terlebih dahulu kita melihat bagaimana model keber-islam-an menurut bissu dan toboto sendiri. Islam yang diyakini bissu dan toboto, tentu berbeda dengan Islam yang diyakini oleh warga yang fanatik tadi. Di Pangkep sendiri, kepercayaan mengenai kekuatan yang tidak kasat mata atau kekuatan dewata masih sangat kuat. Sehingga, kepercayaan terhadap bissu kental adanya.

Bagi bissu sendiri, tidak pernah menganggap dirinya dengan aliran kepercayaan selain Islam. Hal ini mungkin masih dilatar belakangi oleh ketakutan mereka saat pemberontakan dan gerakan pemurnian Islam yang dilakukan oleh kelompok Kahar Muzakkar. Namun apa yang ditemukan di lapangan, berbeda dengan temuan saya saat melakukan kajian pustaka. Para peneliti atau penulis selalu menyematkan mereka sebagai aliran kepercayaan yang berbeda, aliran kepercayaan ini akrab dengan kata attoriolong yang ada pra-Islam seperti temuan (Nurlina dan Soedarsono 1997, Lathief 2004, Umar 2008, Andini 2017, Triadi 2018). Walaupun memang, ini adalah tugas peneliti untuk memberikan interpretasi.

Dari wawancara yang dilakukan dengan bissu Vira, dirinya memberikan kesan yang berbeda tentang Islam. Baginya, konsep adat atau budaya ada sebelum Islam diterima dan mengakar sebagai sebuah ideologi. Karena itu, menjalankan syariat-syariat Islam tanpa mengurangi kepercayaan terhadap adat dan budaya adalah sebuah kombinasi yang patutnya ada bagi masyarakat Bugis.

“iyero nak, beda metoi we' yero ko agamae, si bawa yae he, nasengi musyrik. Tapi, yero idi ri sese ta, de na musyrik, yero kapang naseng musyrik, ko engka di pano, yero idi mappekoki ro nak puang alla ta'ala meto ri sompa. De na mompo nyede jama-jamangge' sengadinna puang alla ta'ala taroi. Pa rioloi tu ade'e, na agama e, macuai ade' e. Jaji macuai sanro e, na guru e"

Artinya:

“...itu (ritual) nak, memang berbeda dengan agama, dengan ini (ritual), mereka mengatakannya musyrik. Tapi dalam hati kami, tidaklah musyrik, mereka mengatakan musyrik kalau memuat sesajen, kami menggunakan, bentuk sesembahan kepada Allah, tidak aka nada ini pekerjaan (ritual), slain atas izin dan petunjuk Allah. Karena lebih dahulu dilakukan adat (ritual), dibandingkan ritus agama, adat adalah yang tertua. Jadi lebih dahulu dukun (Bissu), dibandingkan guru (ustaz)..." (bissu Vira, 18 Januari 2019)

Ini mengartikan, jika bagaimanapun Islam mengakar sebagai sebuah ajaran dan mengatur pola hidup beragama, bissu dan beberapa golongan masyarakat akan tetapi percaya dengan ritual sebagai pelengkap dari sebuah keber-Islam-an. 
Dalam menjalankan syariat Islam, bissu sendiri selalu ada pada ranah yang temporal. Artinya, ketika menjalankan syariat Islam bissu selalu menyesuaian dengan perawakan laki-laki. Namun, mereka akan berperawakan seperti perempuan kembali setelah itu. Dengan begitu, Islam selalu mengembalikan bissu pada fitrahnya sebagai pemeluk agama Islam. Berbeda dengan toboto, pandangan menyimpang terhadap mereka hanya sebatas dari relasipertukarannya dengan bissu, sedangkan dalam menjalankan syariat, mereka tak ubahnya seperti lelaki kebanyakan.

Selama melakukan penelitian di Pangkep, saya sengaja mendatangi Bissu pada waktu-waktu umat muslim harus menjalankan sholat. Apa yang saya dapati, mereka malah memilih tidak melaksanakan sholat, dan tetap menemani saya melanjutkan perbincangan. Peristiwa yang berbeda saat saya melakukan konfirmasi data lapangan di Bone, saya mendatangi ketua komunitas bissu Bone. Saat sedang asik melakukan perbincangan sekitar pukul 12.00 siang, azan berkumandang dari masjid yang tidak jauh dari tempat tinggalnya. Saat itu pula ia meminta izin dan bergegas untuk ke masjid. Mendatangi dua bissu di Bone, saya selalu disambut dengan perawakan bergamis yang mereka gunakan (lihat Gambar 3 dan Gambar 4).
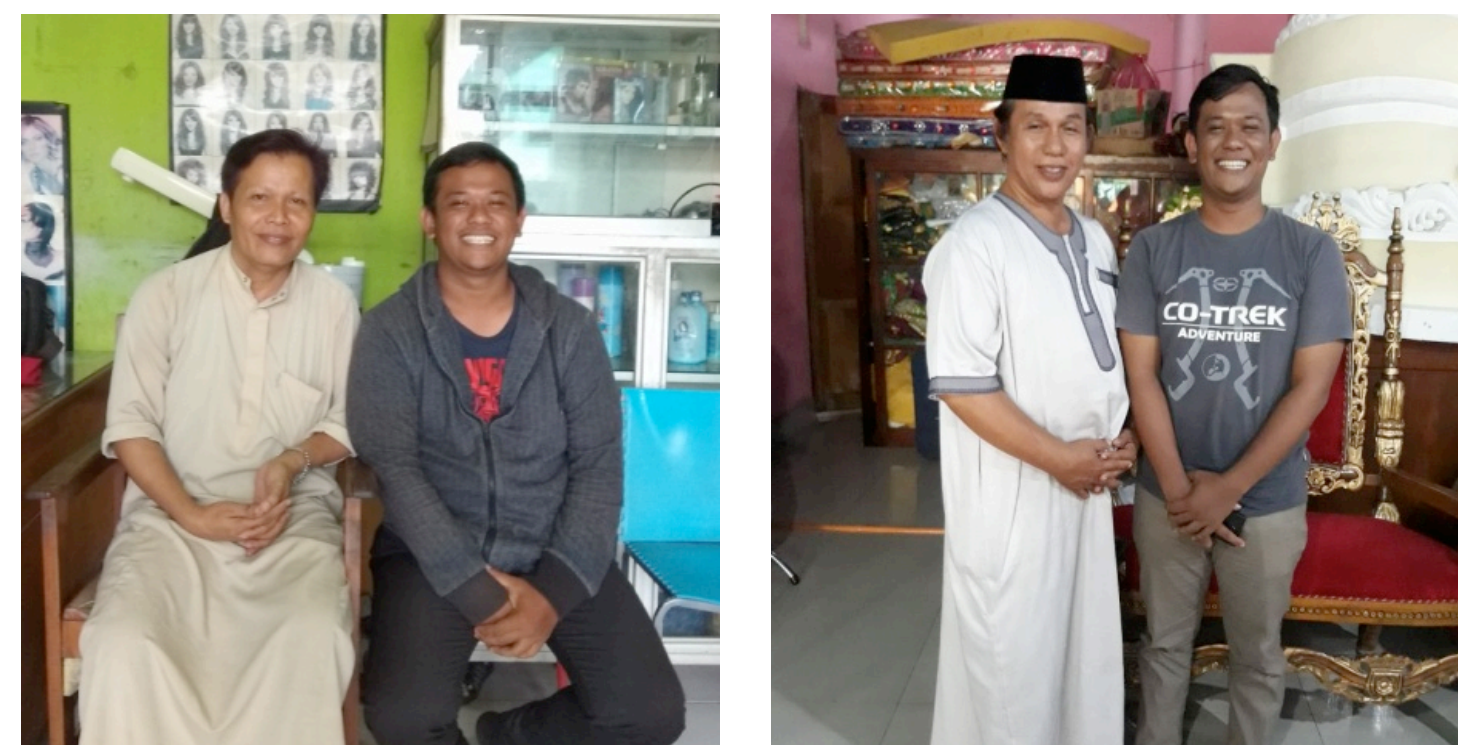

Gambar 3. Perawakan bissu Andi Marsela (kiri tampak dari pembaca).

Gambar 4. Perawakan bissu Angel (kanan tampak dari pembaca) dalam menerima tamu (Dokumentasi Pribadi, 2018).

Selain itu, bissu yang telah berumur tua, beberapa memilih untuk melaksanakan ibadah haji. Saat saya melakukan wawancara dengan bissu Vira, dirinya mengungkapkan jika dalam waktu dekat ia akan melaksanakan umroh. Dirinya mengaku mengalami hambatan saat ingin mendaftar pada agen perjalanan umroh, karena alasan administrasi dan perawakannya sebagai seorang yang bertabiat perempuan. Seperti yang diungkapkan Sharyn dalam penelitiannya: 
Ketika calabai pergi naik haji atau umroh, bagaimanapun, mereka umumnya harus berdandan seperti laki-laki, kemudian jika seorang calabai sudah menjadi haji, bila mereka melakukan hubungan seksual hubungan seksual dengan pria, akan dipandang melakukan hubungan dosa (Davies, 2018).

Namun, saat menkonfirmasi ke bissu Vira, ia enggan menjawab jika sepulangnya dari umroh akan memutuskan hubungan dengan toboto-nya, ia hanya memberi gambaran jika saat bangun pagi, agar tetap bertenaga menjalani hari, ia ingin selalu ditemani oleh seseorang yang tentu membuatya semangat. "kalau pagi, kita juga mau bangun dengan semangat, lewat merekalah semangat kamu" (bissu Vira, 13 November 2018).

Saat saya juga memberanikan diri mengkonfirmasi toboto bissu Vira, awalnya dia terasa malu untuk mengungkapkan hubungan diantara mereka. Ia hanya memberikan pernyataan jika tidak akan melupakan orang yang telah menujukannya jalan kebaikan:

"riolo memenni Vira na alaka, nagi ana' ka. Maega, na paccueka aga ma'pasang lamming. Pammulanna ro de wisseng $i$, maittapa maccue, nappa maccana mappasang. Pa riolo mai ro, de pa gaga maega pallamming, bangsana makokkoe. De meto welo salai Vira apa alena pitakka laleng"

Artinya:

Dari dulu saya sudah ikut sama Vira, dia sudah menganggap saya sebagai anak. Banyak peristiwa, saya pernah diikutkan untuk merias penggung pengantin. Awalnya saya tidak tahu, setelah lama mengikuti lalu saya bisa. Karena dulu, belum banyak yang menawarkan jasa rias panggung pengantin, saya tidak bisa meninggalkan Vira karena dia yang menujukkan saya jalan kebaikan (Barki, 31 Januari 2019).

Dengan begitu, terlihat jelas bahwa hubungan mereka akan selalu terjalin. Walaupun sepulangnya dari ibadah umroh.

Kembali pada konflik antara dua kubuh ini pada dasarnya bermula ketika tata aturan lisan, digantikan dengan tulisan, saat itu norma moral menjadi sasaran utama aturan, ketika aturan-aturan lisan bermuatan moral tersebut digantikan dengan aturan-aturan tertulis yang konon lebih modern, maka masyarakat tradisional mulai kehilangan kekuatannya (Said, 2016). Selain itu, pemuka adat juga kehilangan kekuatan saat sosok karismatik dari mereka mulai pudar, yang kian sialnya karena tergantikan dengan sosok pemerintah yang menjabat dengan masa yang tergolong singkat. Begitu juga saat saya mulai bertanya tentang konsep toboto yang dipelihara oleh bissu, beberapa tetuah adat sangat menyayangkan dengan isu yang digulirkan kepada mereka. Namun mereka seakan pasrah untuk isu ini, tidak banyak yang mampu mereka uraikan saat saya mulai mencecar tentang konsep toboto, bahkan hanya menjadi bahan lelucon. 
Hadirnya Islam juga merupakan malapetaka besar bagi mereka (bissu dan toboto). Sebab isu mengenai praktek homo-seksual mulai disematkan pada kelakuannya. Namun berbeda dengan apa yang dikatakan oleh salah satu dewan adat lainnya, yang juga menempati posisi kepala dinas di Pemerintahan Pangkep yang mengungkapkan:

"melihat mereka, bukan praktik LGBT, dulu itu, mereka memang dipakai oleh kerajaan. Sekarang juga masih dipakai sama petani, tidak mau itu petani turun sawah, kalau belumpi mappalili bissu" (Pak Adnan, 10 November 2018) pungkasanya sambil menepis isu LGBT dilekatkan pada bissu dan toboto.

Artinya, walaupun mereka memiliki kelakuan yang menyimpang. Namun oleh beberapa warga yang masih percaya, mereka tidak akan turun ke sawah, jika ritual mappalili belum dilaksanakan. Dengan begitu, kelakuan mereka tertutupi oleh fungsinya sebagai bissu yang kadang juga melakukan praktik penyembuhan (sandro).

Salah seorang informan lain saya mengatakan jika tradisi bissu harus tetap dijalankan, namun kepercayaan tentang rapal, doa, dan mantranya harus dihilangkan. Agar generasi muda tetap mendapatkan pengetahuan tentang mereka (bissu). “...kalau kita laksanakan, ndak papa ji, cuma ritualnya harus ditulis, yang dihilangkan itu cuma kepercayaanya, supaya tetap orang membaca" (H. Taliu Badau, 11 November 2018) ungkap pakar sejarah Pangkep ini.

Dengan demikian, kedua kubuh ini terjadi negosiasi dingin, yang berangkat dari pendapat masing-masing. Golongan Islam yang fanatik dengan orangorangnya yang terpelajar selalu menyerang bissu dan toboto sebagai pelaku homo-seksual. Sementara dewan adat yang menduduki pemerintahan, menyelamatkan mereka (bissu dan toboto) karena posisinya dahulu sebagai penasehat raja dan penjaga benda-benda kerajaan. Berbeda lagi dengan akademisi dan pemerhati budaya, memilih untuk bersikap netral, dengan catatan kepercayaan tengang rapal dan mantra yang dihilangkan.

\section{Kesimpulan}

Narasi mengenai kehidupan bissu, umumnya selalu difokuskan pada Kecamatan Segeri, dengan alasan bissu, rumah arajang dan benda-benda sakral lainnya berada di kecamatan itu. Padahal, setelah saya telusuri, cuma satu bissu yang tinggal di rumah arajang, itupun dirinya mengaku sering meninggalkan rumah saat perbekalan menipis. Artinya, selama ini bissu dinarasikan dengan melihat ritual yang selalu berpusat pada rumah arajang. Pendekatan untuk melihat mereka bercengkrama dengan masyarakat tempat tinggal asli mereka, khusunya di kecamatan lain belum terlalu banyak dilakukan. 
Bissu dan toboto umumnya selalu digunakan untuk pelegalan penyimpangan secara kultural, namun setelah melakukan penelitian ini, saya berasumsi jika apa yang mereka lakukan adalah kerja kemanusiaan, untuk saling membantu sanak saudara mereka yang berada dalam tataran ekonomi yang lemah. Makanya bissu memelihara toboto untuk membantunya melakukan aktivitas keseharian, termasuk pada beberapa aktivitas yang sifatnya rahasia. Negosiasi antara dewan adat dan warga yang beraliran Islam fanatik, bagaikan bom waktu yang suatu saat siap meledak. Dewan adat diwakili oleh orang-orang yang memiliki kekuasaan dari keturunan bangsawan, sedangkan kelompok Islam tadi juga diwakili oleh tokoh agama dan beberapa warga yang memiliki pendidikan memadai.

Dalam artikel ini, saya merekomendasikan suatu objek lain untuk melihat bissu, yakni toboto. Dengan adanya penelitian ini, saya berharap mampu mengisi kekosongan narasi tentang toboto, karena dengan begitu, bissu tidak hanya dilihat sebagai satu objek kajian saja. Namun ada objek lain yang berpotensi menjelaskan lebih banyak mengenai bissu, selain mereka sendiri. Namun penelitian ini harus dilakukan dengan berhati-hati dan teliti, mengingat data yang diinginkan bersifat personal dan pribadi.

\section{Daftar Pustaka}

Ahimsa-Putra, Heddy. S. (1987). Etnografi Sebagai Kritk Budaya: Mungkinkah di Indonesia? Jerat Budaya , 16-40.

Al-Bayqunie, Pepi (2016). Calabai Perempuan dalam Tubuh Lelaki. Tanggerang Selatan: Javanica.

Andini, Batari. O. (2017). The Islamization in Bugis Society during the Darul Islam Era under Kahar Muzakar in 1960s. Dinika Academic Journal of Islamic Studies , 23-34.

Darmapoetra, Juma. (2014). Bissu Perantara Dewa. Makassar: Arus Timur.

Davies, Sharyn. G. (2018). Keberagaman Gender di Indonesia. Jakarta: Penerbit Obor.

Fajriani. (2015). (Skripsi) Upacara Mappalili oleh Pa'Bissu di Kelurahan Bontomate'ne Kecamatan Segeri Kabupaten Pangkep. Jurusan Perbandingan Agama: Universitas Islam Negeri Alauddin Makassar.

Gibson, Thomas. (2009). Kekuasaan, Syeikh dan Ambtenaar Pengetahuan Simbolik dan Kekuasaan Makassar 1300-2000. Makassar: Ininnawa.

Gonggong, Anhar. (1992). Abdul Qahhar Mudzakkar Dari Patriot Hingga Pemberontak. Jakarta: PT. Gramedia Widiasarana.

Hakim, Abdul. (2014). A Long Path of Bissu in South Sulawesi, Indonesia Fro Glory to Disappearance. Maluku Utara: Maba, East Halmaher. 
Harvey, Barbara. S. (1974). Tradition, Islam, And Rebelion: South Sulawesi 19501965. A Thesis Doctor of Philosophy: Cornell University.

Kaseng, Syamsuddin. (2008). Menelusuri Jejak Kehadiran Pangkep Sebagai Sumbangan bagi Pembangunan Nasional di Derah. In A. M. Magassing, Sejarah Kelahiran Pangkep (pp. 53-70). Pangkep: Dinas Kesejahtraan Sosial dan Tenaga Kerja.

Lathief, Halilintar. (2004). Bissu Pergulatan dan Perannya di Masyarakat Bugis. Depok: Desantara.

Magassing, Andi. M. (2008). Sejarah Kelahirang Pangkep. Pangkep: Dinas Kesejahtraan Sosial dan Tenaga Kerja Kabupaten Pangkep.

Makkulau, Farid. (2008). Manusia Bissu . Makassar: Pustaka Refleksi.

Mappangara, Suriadi. (2003). Sejarah Islam di SUlawesi Selatan. Makassar: Biro KAPP Sekretaris.

Mattulada. (1998). Sejarah, Masyarakat dan Kebudayaan di Sulawesi Selatan. Ujung Pandang: Lembaga Penerbit Universitas Hasanuddin.

Pelras, Christian. (1996). The Bugis. Inggris: Blackwell Limited Oxford.

Said, Muhammad. (2016). Peran Bissu dalam Masyarakat Bugis. Seminar Nasional Pendidikan Ilmu-Ilmu Sosial Membentuk Karakter Bangsa dalam Rangka Daya Saing Global (pp. 69-78). Makassar: Fakultas Ilmu Sosial Universitas Negeri Makassar dan Himpunan Sarjana Pendidikan IlmuIlmu Sosial Indonesia.

Salihima, Syamsuez. (2015). Peta politik di Sulawesi Selatan Pada Awal Islamisasi. Jurnal Rihlah, 33-44.

Scott, James. C. (1972). Patron-Client Politics and Political Change in Southeast Asia. American Political Science Association, 91-113.

Simatupang, Lono. L. (2017). Etnografi. Power Point Persentase Pengajaran Metode Penelitian Etnografi. Universitas Gadjah Mada.

Spradley, James. P. (1980). Metode Etnografi. Yogyakarta: Tiara Wacana.

Suliyati, Titiek. (2018). Bissu: Keistimewaan Gender dalam Tradisi Bugis. Jurnal Ilmiah Kajian Antropologi, 52-61.

Sumyati. (2006). Strategi Adaptasi Masyarakat dalam Menghadapi Bencana Banjir Pasang Air Laut di Kota Pekalongan. Jurnal Prisma , 51-72.

Thamrin, Umar. (2015). How Economy Matters to Indigenous Identity of Bissu, Transgender Priests of South Sulawesi, Indonesia. Singapore: Asia Research Institute.

Triadi, Feby. (2018). Calabai Dalam Tubuh Lelaki: Telaah Epistemologi Fenomenologi Pada Novel Karya Pepi-Albaiqunie. Jurnal Pangadereng , 2940. 